\title{
Influence of eating habits and socioeconomic profile on students' oral health
}

\author{
Influência dos hábitos alimentares e perfil \\ socioeconômico na saúde oral de escolares
}

\author{
Laís Cardozo dos SANTOS ${ }^{1}$ iD 0000-0002-4234-830X \\ Daniela da Silva OLIVEIRA ${ }^{2}$ iD 0000-0002-3483-5407 \\ Ana Claudia Fontes da SILVA ${ }^{3}$ iD 0000-0003-1947-9384 \\ Ângela Maria de Souza PIMENTEL ${ }^{3}$ iD 0000-0002-4018-8373 \\ Mariana Dias Flor RIBEIRO4 ${ }^{4}$ 0000-0003-0757-3410 \\ Letícia Côgo MARQUES ${ }^{3}$ iD 0000-0002-5701-6842
}

\section{ABSTRACT}

Objective: To evaluate the association between the presence of tooth decay and the eating habits, oral hygiene habits, and socioeconomic profile of children in the fifth grade at the state secondary and elementary school Pedro Simão in Alegre, ES. Methods: Questionnaires were used to evaluate the socioeconomic profile, eating habits, and oral hygiene habits of the fifth-grade students. Then an epidemiological survey on dental caries and on the presence of dental plaque was conducted. After the first clinical examination, the students completed educational and preventive activities about nutritional and oral hygiene education. One week after the performance of the educational actions, the dental plate index was evaluated. Results: The variables "family income" and "number of members" in the family were statistically significant $(p \leq 0.20)$ with caries association using a bivariate regression analysis. However, variables related to diet did not present a significant association with caries ( $p>0.20)$. The initial and final IHOS were 1.85 and 0.92 , respectively, which was significantly lower after the intervention $(p<0.05)$. The DMFT was 1.81, which is higher than the average for the Southeast Brazil, obtained in 2010 by the Brazilian National Oral Health Survey (SB Brazil). Conclusion: The caries prevalence was high in the sample studied, and the intervention was important to reduce the students' dental plaque levels and improve their oral hygiene condition. Thus, it is necessary to develop continuous educational programs so that oral health is maintained.

Indexing terms: Dental caries. Food and nutritional education. Students.

\section{RESUMO}

Objetivo: Avaliar a associação entre a presença de cárie dentária com a dieta alimentar, hábitos de higiene oral e o perfil socioeconômico de crianças do $5^{\circ}$ ano da Escola Estadual Ensino Fundamental e Médio Pedro Simão do Município de Alegre, Espírito Santos, Brasil.

$\boldsymbol{\nabla} \boldsymbol{\nabla} \boldsymbol{\nabla} \nabla$

1 Universidade Federal do Espírito Santo, Centro de Ciências Exatas, Naturais e da Saúde, Faculdade de Nutrição. Av. Fernando Ferrari, 514 , Goiabeiras, 29075-910, Vitória, ES, Brasil. Correspondência para / Correspondence to: LC SANTOS. E-mail: <lays-c@hotmail.com.br>

2 Universidade Federal do Espírito Santo, Centro de Ciências Exatas, Naturais e da Saúde, Departamento de Farmácia e Nutrição. Alegre, ES, Brasil.

3 Universidade Federal do Espírito Santo, Seção de Atenção à Saúde e Assistência Social. Alegre, ES, Brasil.

${ }^{4}$ Universidade Estadual de Campinas, Departamento de Odontologia Restauradora. Piracicaba, SP, Brasil.

$\boldsymbol{\nabla} \boldsymbol{\nabla} \boldsymbol{v}$

Como citar estar artigo / How to cite this article

Santos LC, Oliveira DS, Silva ACF, Pimentel AMS, Ribeiro MDF, Marques LC. Influence of eating habits and socioeconomic profile on students' oral health. RGO, Rev Gaúch Odontol. 2019;67:e201909. http://dx.doi.org/10.1590/1981-86372019000093629 
Métodos: Foram aplicados questionários para avaliar o perfil socioeconômico, os hábitos alimentares e hábitos de higiene oral de 26 escolares do $5^{\circ}$ ano; em seguida, foram realizados levantamento epidemiológico em relação à cárie dentária e a presença de placa bacteriana. Após o primeiro exame clínico, foram realizadas atividades educativas e preventivas em educação nutricional e de higiene oral. Uma semana após a aplicação das ações educacionais, o índice de placa foi reavaliado. Resultados: As variáveis 'renda familiar' e 'número de membros na família' foram estatisticamente significativas ( $p \leq 0.20)$ pela análise de regressão bivariada, tendo associação com a cárie, porém, as variáveis relacionadas à dieta não apresentaram associação significativa ( $p>0.20)$ com a cárie. O IHOS inicial foi 1.85, e o final 0.92, sendo significativamente menor $(p<0.05)$ após a intervenção realizada. O CPO-D foi de 1.81, resultado acima da média da região Sudeste do Brasil, obtida em 2010 pela Pesquisa Nacional de Saúde Bucal (SB Brasil). Conclusão: A prevalência de cárie foi elevada na amostra estudada e a intervenção realizada foi de suma importância para reduzir os níveis de placa bacteriana dental dos escolares e melhorar a condição da higiene oral, afirmando que é necessário desenvolver ações educativas continuadas para que a saúde seja mantida.

Termos de indexação: Cárie dentária. Educação alimentar e nutricional. Escolares.

\section{INTRODUCTION}

The development and implementation of effective measures of control of diseases requires the identification of the factors influencing the health status of the population [1]. And, thus, due to the functional and psychosocial impact of decay, understanding it as a multifactorial disease [2] is important for its control.

When evaluating the factors associated with tooth decay, great influence of poor socioeconomic condition of families has been observed in the development of oral diseases $[3,4]$. The high rates of prevalence of carious lesions are related to the socioeconomic profile, guardians' education level and number of family members [5]. This association points to the need for ensuring the access of the neediest population to public policies, especially of health and education [6]. Therefore, creating strategies to reduce social inequalities becomes urgent.

The parents' knowledge of oral hygiene in children [7] and the knowledge transmitted through advices by oral hygiene professionals [8] are important for the prevention of tooth decay, which, in turn, influences the frequency of tooth brushing, the flossing and the brushing technique, being very important to oral health $[8,9]$.

The practice of healthy eating in children is another important variable in the etiology of caries disease [10], because childhood is the most appropriate period for the development of healthy eating habits that respect the characteristics of each child [11].

A balanced diet influences oral health in many ways and the nutritional deficiency may cause defects in the structure of the teeth during their development period [12]. Excess consumption of sugars, particularly sucrose, can favor the development of tooth decay [13]. Thus, the guardians' awareness regarding the control of diet and the intake of healthy foods is a relevant factor for preserving the child's oral health [14].

In this way, through a good nutritional education, instructions concerning the oral hygiene and reduction in the socioeconomic inequality, developing healthy habits that may reduce the incidence of carious lesions is suggested. In view of this, this study aimed to evaluate associations between the presence of tooth decay, diet, oral hygiene habits and socioeconomic profile of students of the municipality of Alegre, ES, and, through actions of nutritional and oral hygiene education, promote health and prevent tooth decay in childhood.

\section{METHODS}

The study's participants were twenty-six children in the 5th grade at the state secondary and elementary school Professor Pedro Simão in the municipality of Alegre, which is located at the state of Espírito Santo, about $60 \mathrm{~km}$ from the city of Cachoeiro de Itapemirim. The municipality covers an area of $778.6 \mathrm{~km}^{2}$. According to the IBGE (Brazilian Institute of Geography and Statistics), the population of the municipality is 32,146 inhabitants [15].

\section{Study design}

This study was conducted in 2017, after approval by the Research Ethics Committee of Faculdade Federal do Espírito Santo, under the number 64939416.0.00005063, approved in July 11, 2017.

During its performance, 5 visits to the school were made: at first, questionnaires were applied to the students' parents and/or guardians, in which personal information such as name, age, date of birth, education, socioeconomic 
condition and dietary habits were obtained. The other questionnaire consisted of questions assessing the attitude and knowledge of the guardians regarding dental habits.

In the second visit, an epidemiological survey on oral health conditions was carried out, evaluating the experience of tooth decay and the oral hygiene through a clinical examination (figure 1, A and B). The following indexes were used: Decayed, missing and filled teeth (DMFT) index and Simplified Oral Hygiene Index (IHOS). The clinical examinations were performed by a single examiner (dental surgeon), which used natural light, gloves and disposable wooden spatulas.

For assessing the DMFT index, the component " $\mathrm{C}$ " corresponded to carious teeth, " $\mathrm{M}$ " to missing teeth (extracted or with prescription of extraction), " $F$ " to filled teeth, and " $D$ " to dentition. " $C$ " and " $M$ " indicates current history and "F" corresponds to past cavity history [16].

For assessment of the Simplified Oral Hygiene Index (IHOS), a dye consisting of basic fuchsin (2\%), sodium saccharin, lactose, sodium cyclamate and excipients, in tablets, was used. During the examination, the examiner applied the previously ground tablets to the vestibular surfaces of the teeth $16,11,26,31$ and lingual surfaces of the teeth 36 and 46 (figure 1, C and D). Scores from 0 to 3 were given, according to the number of dental plaques on each teeth evaluated, in which: 0 (surface without plaque); 1 (one-third of the surface covered with plaque); 2 (twothirds of the surface covered with plaque); 3 (the entire
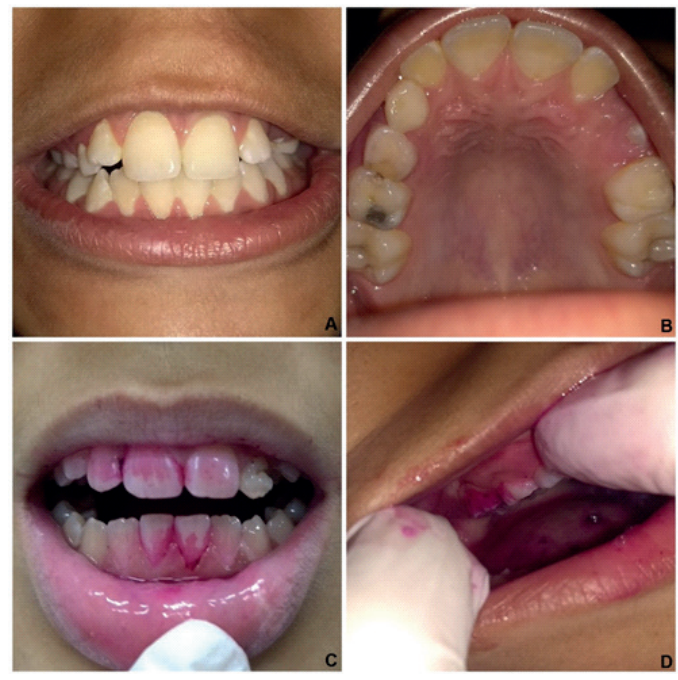

Figure 1. Oral cavity clinical aspects. A, B: Presence of dental plaque and carious lesions. B, C: Presence of plaque evidence in the anterior and posterior teeth. surface covered with plaque) [17]. After the evaluation, an arithmetical mean was calculated, and, according to the result, the level of the students' oral hygiene was evaluated. The values of arithmetic mean were classified as follows: between 0 and 1, good oral hygiene; from 1 to 2 , regular; and between 2 and 3, poor [18].

During the third and fourth visits, educational activities about eating habits and oral hygiene were carried out, including advices and supervised brushing. In the fifth visit, oral clinical examination was performed again to reevaluate the IHOS. After the activities, all children who needed orthodontic intervention were referred to be cared for in health units of their regions.

Data obtained were added to a database, using Microsoft Excel 2010 software. Statistical analysis of IHOS was conducted using paired t-test with two samples $(p \leq 0,05)$, with a significance level of $5 \%$ and $95 \%$ confidence intervals. The DMFT index was calculated by dividing the total of decayed, missing and filled permanent teeth by the total of children examined.

For analyzing the data of the questionnaires, the STATA 14 software was used. Initially, bivariate regression analyses were conducted, and those variables whose significance level was $(p \leq 0,20)$ were included in the multiple analyses. For a significant relationship, it was considered the " $p$ " value of the variable and the constant of less than or equal to 0.05 with $95 \%$ confidence interval.

\section{RESULTS}

Twenty-six students aged between 10 and 12 years were examined, being $57.6 \%$ female and $42.3 \%$ male, with prevalent family income lower than or equal to 1 minimum wage.

Most of the sample reported already having received dental treatment $(73.07 \%)$, and public service was the most used (53.84\%). Most of the parents and/ or guardians (69.23\%) reported not having received information on the prevention of diseases associated with oral health.

Of the total of children evaluated, $57.7 \%$ had active tooth decay, and the DMFT index found was 1.80 $( \pm 1.93)$ (table 1$)$. The initial IHOS index obtained an overall average of $1.85( \pm 0.53)$; and the final IHOS, $0.92( \pm 0,50)$ (figure 2). In relation to oral hygiene habits, $73.07 \%$ reported brushing over 2 times a day and only $50 \%$ of the students evaluated did not use dental floss. 
Table 1. Students' average DMFT index.

\begin{tabular}{lcccccc}
\hline & \multicolumn{5}{c}{ RESULT OF THE DMFT INDEX } \\
\cline { 2 - 7 } Age group & $\mathrm{n}$ & $\mathrm{C}$ & $\mathrm{M}$ & $\mathrm{F}$ & Average DMFT \\
\hline 10 to 12 years & 26 & 27 & 1 & 19 & 1.81 \\
\hline
\end{tabular}

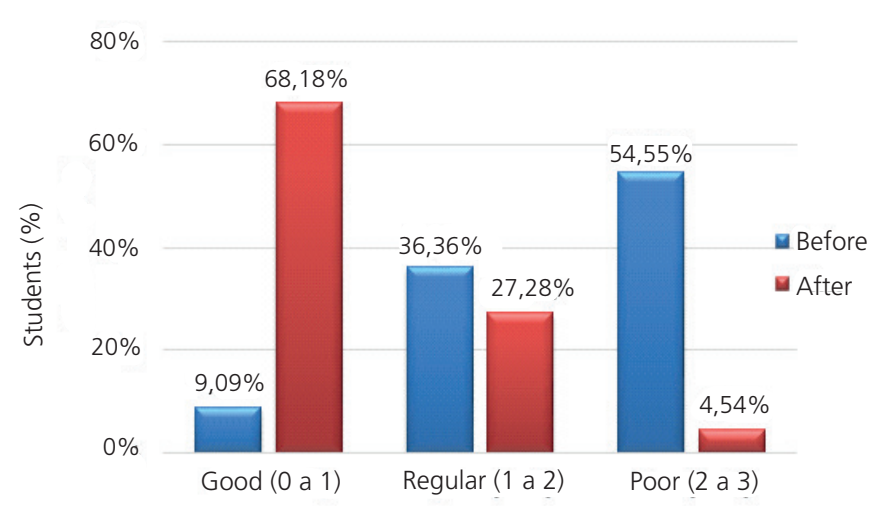

Figure 2. Students' percentage distribution of income.

Regarding specific questions about eating habits, $50 \%$ of parents and/or guardians reported that their children had a habit of consuming high sugar content food and drinks (figure 3). However, the variables sugar intake, intake of fruits and vegetables, intake of sugary drinks, intake of processed foods, intake of candies and intake of

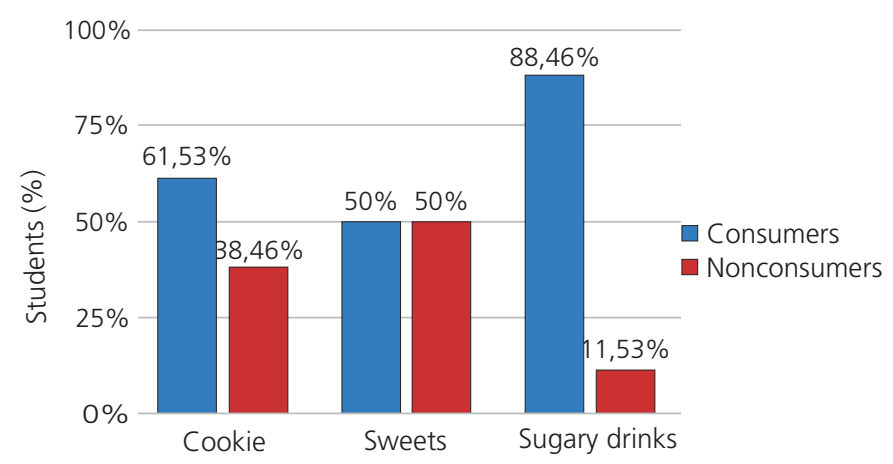

Figure 3. Oral Hygiene index (IHOS) of students before and after the intervention. cookies showed no significant association ( $p>0.20)$ with the presence of tooth decay in the sample evaluated.

The variable family income was statistically significant $(p=0.040)$, as well as the number of family members $(p=0.033)$. To validate the results, the fitted model/residual analysis was performed (table 2).

\section{DISCUSSION}

Tooth decay is pointed to as the main cause of tooth loss [19] and a central public health problem in Brazil [20]. It is a disease considered polarized, more prevalent in the population in unfavorable socioeconomic conditions [19]. This occurs probably due to educational level, lifestyle, degree of knowledge, basic sanitation, and lack of access to health services and information [21].

The variable family income, according to the results found in this study, had significant influence on the development of tooth decay. This aspect reaffirms the results by Galindo et al. [22], who found association between the family income and the average DMFT index, in which families whose income was equal to or lower than 5 minimum wages showed index of 0.44 , which is significantly lower compared with the index of 1.70 , shown for children with family income lower than 1 minimum wage.

Our results were similar to those of the study by Meneghim et al. [23] in Piracicaba (SP), Brazil, in which association between dental caries and socioeconomic variables was observed, including family income, which was statistically significant $(p<0.0001)$. In another study,

Table 2. Residual analysis of the factors associated with tooth decay.

\begin{tabular}{lcccc}
\hline & & \multicolumn{3}{c}{ CARIES } \\
\cline { 2 - 5 } Dependent variable & Odds Ratio & $\mathrm{P}>|z|$ & [95\% - Confidence interval] \\
\hline Family income & .0705549 & 0.030 & .0064003 & 7777715 \\
Family members & .0814692 & 0.040 & .0074744 & .887997 \\
\hline
\end{tabular}


by Narvai et al. [24] the worst indicators of the disease were found in children from lower-income families living in municipalities with poor economic indicators and without access to treated and fluoride water.

Regarding the analysis of the DMFT index, the initial average of this study, 1.80, was similar to that in the study performed in João Pessoa, Paraíba, Brazil, by Moraes et al. [25], in which they found an average of 1.90. Unlike the data found by Hoffmann et al. [26] in the state of São Paulo, an index of 3.37 was found in students from public schools. However, this difference in the data can be explained by the different methodologies used in each study. Therefore, data from this study confirm that the DMFT index is important not only to plan prevention strategies, but also to serve as indicator for health services.

Regarding the analysis of IHOS, one can observe that the students showed reduction in the plaque index after receiving advices on oral hygiene and nutrition. A similar result was observed by Szpilman et al. [27], in Vitória, ES, in which reduction in the mean plaque index, from 1.84 to 1.71 , after 14 days of educational activities was confirmed, being significant $(p<0.05)$. In study conducted by Silveira et al. [28] in Rio de Janeiro, with similar methodology, in which the visible initial mean plaque index showed reduction of $29 \%$ compared with the final mean plaque index of $11 \%$, showing a significant reduction in bacteria biofilm on the dental surfaces after a cycle of educational activities. Thus, the program for health promotion was effective regarding the control of plaque, reducing the mean visible plaque index in the children cared for to an acceptable level. These data reinforce the theory that the development of educational programs for health education and health promotion is essential and notorious [8].

In relation to the association between tooth decay and diet, the values found in our study were not significant. However, the children studied showed high intake of sugary foods. Soraggi et al. [29], observed that sugary food intake occurs four times a day or more, and the main time for consumption of sugary food is between meals in $75.7 \%$ of the cases, which makes the oral hygiene still more difficult, and, thus, the consumption of these foods have an important role in the development of tooth decay. In addition, in the study by Figueira and Leite [20] the results show that the index of children who eat sugar several times a day was relatively high (51.8\%) even after participating in oral health care programs. These data reinforce the theory that any preventive measure used in isolation against caries will be satisfactory 20 [20], but investing in collective motivation actions and encouraging the teaching-learning process concerning health promotion is necessary.

Therefore, the results of this study and the reports of the aforementioned studies show that awareness and education regarding oral health and nutrition, along with reduction in the socioeconomic inequalities, are essential to prevent plaque and, consequently, tooth decay. Further investigation is required to find out why the variables related to nutrition were not significantly associated with tooth decay.

\section{CONCLUSION}

The results of this study suggest association between the variables "family income" and "number of members in the family" with the development of dental caries, which reinforces the multifactorial aspect of the caries disease. The intervention promoted significant improvement in the levels of dental plaque, highlighting the importance of preventive measures and health promotion. In addition, the average found in the DMFT index of students from the school EEEF Professor Pedro Simão, in Alegre, was greater than the national average in the Southeast Brazil, and the prevalence of caries in the population studied was high. Thus, a continuous monitoring of the students' oral health is important, in addition to the need for developing preventive actions so that health care can be maintained and improved.

\section{Collaborators}

LC SANTOS, data curation; investigation; methodology; project administration; validation; visualization; writing-original draft. DS OLIVEIRA: conceptualization; data curation; formal analysis; validation; visualization; writing-review \& editing. ACF SILVA: conceptualization; data curation; formal analysis; writing-original draft; writing-review \& editing. ÂMS PIMENTEL: conceptualization; data curation; formal analysis; visualization; writing-review \& editing. MDF RIBEIRO: formal analysis; investigation; methodology; validation; writing-review \& editing. LC MARQUES: conceptualization; data curation; formal analysis; investigation; methodology; project administration; supervision; visualization; writing-review \& editing. 


\section{REFERENCES}

1. Ardenghi TM, Piovesan C, Antunes JLF. Desi-gualdades na prevalência de cárie dentária não tratada em crianças préescolares no Brasil. Rev Saúde Pública. 2013;47(3):129-37. http://dx.doi.org/10.1590/S0034-8910. 2013047004352

2. Vieira PR, Fragelli CMB, Jeremias $F$, Santos PLAM. Qualidade de vida e percepção estética da cárie dentária. Rev Bras Promoç Saúde. 2018;31(1):1-9. http://dx.doi. org/10.5020/18061230.2018.6649.

3. Piovesan C, Mendes FM, Antunes JLF, Ardenghi, TM.Inequalities in the distribution of dental caries among 12-year-old Brazilian schoolchildren. Braz Res Oral. 2011;25(1):69-75. http:// dx.doi.org/10.1590/S1806-83242011000100012

4. Cruz MGBD, Narvai PC. Caries and fluoridated water in two Brazilian municipalities with low prevalence of the disease. Rev Saude Publica. 2018;9:52-28. http://dx.doi.org/10.11606/ s1518-8787.2018052016330

5. Souza ME, Pereira SM, Castilho ARF, Pereira LJ, Pardi V, Pereira AC. Relação entre fatores socioeconômicos, clínicos e saúde bucal em escolares da zona rural: um estudo longitudinal. RFO UFP. 2015;20(2):208-215. http://dx.doi.org/10.5335/rfo. v20i2.5018

6. Hahn RA, Truman BI. Education improves public health and promotes health equity. Int J Health Serv. 2015;45(4):657-78. http://dx.doi.org/10.1177/0020731415585986

7. Winnier JJ, Mehta S, Parmar A, Bhatia R. Pediatric dental procedures: a survey of knowledge and attitudes of parents. Int J Dent Health Sci. 2015;2(5):1171-82.

8. Orsi VME, Pereira AA, Flório FM, Souza LZ, Boaretto P, Pinheiro PPZ. et al. Hábitos e conhecimentos de escolares sobre saúde bucal. RGO, Rev Gaúch Odontol. 2009;57(3): 291-296.

9. Borges TS, Schwanke NL, Reuter CP, Neto LK, Burgos MS. Fatores associados à cárie: pesquisa de estudantes do sul do Brasil. Rev Paul Pediatr. 2016;34(4):489-494. http://dx.doi. org/10.1016/j.rppede.2016.02.013

10. Biral MA, Taddei CAAJ, Passoni FD, Palma D. Cárie dentária e práticas alimentares entre crianças de creches do município de São Paulo. Rev Nutr. 2013;26(1):37-38. http://dx.doi. org/10.1590/S1415-52732013000100004

11. Passos DR, Gigante DP, Maciel FV, Matijasevich A. Children's eating behavior: comparison between normal and overweight children from a school in Pelotas, Rio Grande do Sul. Rev Paul Pediatr 2015;33(1). http://dx.doi.org/10.1016/j. rpped.2014.11.007

12. Feijó SI, Iwasaki KMK. Cárie e dieta alimentar. Rev Uningá. 2014;18(3):44-50.

13. Júnior JALAK, Gonçalves LV, Correia AA. Alimentos x cárie: a ingestão do açúcar em excesso como fator estimulante do desenvolvimento da doença. Cien Biol Saud. 2015;2(2):11-20.

14. Faria GFJ, Figueiredo CM, Simões SB, Mundstokck SK. Análise do consumo de sacarose na dieta dos pacientes em tratamento na Clínica da Faculdade de Odontologia da UFRGS. RFO, 2016;21(1):43-48. http://dx.doi.org/10.5335/ rfo.v21i1.5516
15. IBGE. Instituto Brasileiro de Geografia e Estatística [Internet]. Estatística por cidade e estado [citado 2018 Maio 22]. Disponível em: <https://www.ibge.gov.br>.

16. Freysleben RG, Peres AAM, Marcenes W. Prevalência de cárie e CPO-D médio em escolares de doze a treze anos de idade nos anos de 1971 e 1997, região Sul, Brasil. Rev Saude Publica. 2000;34(3):304-308. http://dx.doi.org/10.1590/S003 4-89102000000300015

17. Queiroz SF, Rodrigues FLMM, Junior CAG, Oliveira BA, Oliveira DJ, Almeida RE. Avaliação das condições de saúde bucal de portadores de necessidades especiais. Rev Odontol UNESP. 2014; 43(6):396-401. http://dx.doi.org/10.1590/1807-257 7.1013

18. Greene JC, Vermillion JR. Oral hygiene index: a method for classifying oral hygiene status. J Am Dent Assoc. 1964;68(1):7-13. http://dx.doi.org/10.14219/jada.archive.1960.0177

19. Landim JR, Neta MCAF, Martins MCA, Nuto SAS, Braga JU. Fatores demográficos e socioeconômicos associados à cárie dentária em uma comunidade nordestina de baixa renda. RFO UPF. 2013;18:75-82. http://dx.doi.org/10.5335/rfo.v18i1.31 04

20. Figueira TR, Leite ICG. Percepções, conhecimentos e práticas em saúde bucal de escolares. RGO, Rev Gaúch Odontol. 2008;51(1):27-32.

21. Goettems ML, Ourens M, Cosetti L, Lorenzo S, ÁlvarezVaz R, Celeste RK. Early-life socioeconomic status and malocclusion in adolescents and young adults in Uruguay. Cad Saúde Publica. 2018; 34(3):00051017. http://dx.doi. org/10.1590/0102-311x00051017

22. Galindo VME, Pereira CAJ, Feliciano OVK, Kovasc HM. Prevalência de cárie e fatores associados em crianças da comunidade do Vietnã Recife. Rev Bras Saude Mater Infant. 2005; 5(2):1-10. http://dx.doi.org/10.1590/S1519-38292005000200009

23. Meneghim CM, Kozlowski CF, Pereira CA, Ambrosano BMG, Meneghim PAMZ. Classificação socioeconômica e sua discussão em relação a prevalência de cárie e fluorose dentária. Ciênc Saúde Coletiva. 2007;12(2):523-529. http://dx.doi. org/10.1590/S1413-81232007000200028

24. Narvai PC, Frazão P, Roncalli AG, Antunes JLF. Cárie dentária no Brasil: declínio, iniquidade e exclusão social. Rev Panam Salud Pública. 2006;19(6):385-93.

25. Moraes SNS, Arsenian BM, Tucci R. Avaliação clínica e utilização do índice CPO-D/ "CEO-d" em crianças da escola municipal José Carlos Porto - Paraty/ RJ. J Health Sci Inst. 2014;32(3):235-40.

26. Hoffmann SHR, Cypriano S, Sousa RLM, Wada SR. Experiência de cárie dentária em crianças de escolas públicas e privadas de um município com água fluoretada. Cad Saúde Pública. 2004; 20(2): 522-528. http://dx.doi.org/10.1590/S0102-3 $11 \times 2004000200020$

27. Szpilman MRA, Miotto BMHM, Barcellos AL. O efeito da informação verbal e demonstração na higiene de crianças de seis a doze anos. UFES Rev Odontol. 2005;7(1):18-29. 
28. Silveira CGLJ, Oliveira V, Padilha NWW. Avaliação da redução do índice de placa visível e do índice de sangramento gengival em uma prática de promoção de saúde bucal com crianças. Pesqui Odontol Bras. 2002; 16(2): 169-174. http://dx.doi. org/10.1590/S1517-74912002000200013

29. Soraggi SBM, Antunes SL, Antunes AAL, Corvino FPM. A cárie dentária e suas condicionantes em crianças de uma escola pública municipal em Niterói, RJ. Pesqui Bras Odontop Clín Integr. 2007;7(2):119-124.

Received on: 7/6/2018 Final version resubmitted on: 6/12/2018 Approved on: 12/2/2019 
LC SANTOS et al. 
